\title{
ETOP: the reference conference in education and training in optics and photonics: an overview of the 12th edition
}

Manuel F. Costa, Mourad Zghal, Zohra Ben Lakhdar, Vasudevan Lakshminarayanan

Manuel F. M. Costa, Mourad Zghal, Zohra Ben Lakhdar, Vasudevan Lakshminarayanan, "ETOP: the reference conference in education and training in optics and photonics: an overview of the 12th edition," Proc. SPIE 9188, Optics Education and Outreach III, 918802 (15 September 2014); doi: $10.1117 / 12.2061211$

SPIE Event: SPIE Optical Engineering + Applications, 2014, San Diego, California, United States 


\title{
ETOP, the reference conference in Education and Training in Optics and Photonics. An overview of the 12th edition.
}

\author{
Manuel F. M. Costa ${ }^{1}$, Mourad Zhgal ${ }^{2}$, Zohra Ben Lakhdar ${ }^{3}$, Vasudevan Lakshminarayanan ${ }^{4}$ \\ ${ }^{1}$ Manuel F. M. Costa, University of Minho, Braga, Portugal \\ ${ }^{2}$ Mourad Zghal, University of Carthage, Tunis, Tunisia \\ ${ }^{3}$ Zohra Ben Lakhdar, University El Manaur, Tunis, Tunisia \\ ${ }^{4}$ Vasudevan Lakshminarayanan, University of Waterloo, Canada
}

\begin{abstract}
The Education and Training in Optics, ETOP, conferences are since 1988 one of the most important and relevant meetings in the field and a reference biennial conference that brings together the international community of optics and photonics educators, the academia and the industry, from all around the world to share experiences and information about learning and teaching optics and photonics at all levels. In this communication we will present the $12^{\text {th }}$ ETOP' edition that toke place rather successfully in Portugal in July 2013 with 214 participants from 38 countries and 140 communications.
\end{abstract}

Keywords: ETOP, optics education, photonics training, women in optics, optics and photonics entrepreneurship.

\section{INTRODUCTION}

The teaching and learning of optics and photonics, critical fields at the core of today's scientific and technological infrastructure, must continually be upgraded and renewed in order to meet the growing demands of research, science and industry for the sake of the sustainable development of our world and humankind. From very early ages at kindergarden and primary school ${ }^{1}$ up to the university an beyond light and optics and its applications should be included in the current curricula by the inherent importance of the scientific topics involved, the training of crucial competencies of observation and critical reasoning a scientists, and all of us indeed, must to acquire ${ }^{2}$, but also upon the appeal these subjects have to our youngsters being directly related to one of our main senses, the vision, but also to the remarkable, still emergent, technologies that our teens and young students uses and identify in their everyday life recognizing the potential of a career in Optics and Photonics.

For long time optics' scientists all around the world realized the importance to the development of optics of providing our school students a good effective education in optics. A large range of quality educational support materials was developed and is readily available ${ }^{3}$. Fortunately this is also true in what concerns materials to be used in hands-on experiments based learning covering virtually all fields of optics and also intended or adapted for use at all school levels. As well lots of meaningful work is being done on in service teacher and educator training in optics and photonics ${ }^{4}$.

The International Conference on Education and Training in Optics, known as ETOP, promoted by SPIE, OSA, IEEE, and ICO, is the principal conference that brings together the international community of optics and photonics educators, leading optics and photonics scientists, academia, and industry, from all around the world to share experiences and knowledge, to discuss, demonstrate and learn about new developments and approaches to teaching in these fields.

Through presentations, panel discussions, workshops and exhibits, it is the intent of this conference to inform professors, students, teachers and professional trainers on how to promote the learning of optics and photonics for the future.

Since 1988, SPIE, the International Society for Optics and Photonics, and OSA, The Optical Society, have sponsored the ETOP conference. The first meeting, initiated by SPIE's Academic Advisory Committee, focused on undergraduate and master's level programs in optics and related fields, the supply and demand for graduates, and academia-industry

Optics Education and Outreach III, edited by G. Groot Gregory, Proc. of SPIE Vol. 9188,

918802 @ 2014 SPIE · CCC code: 0277-786X/14/\$18 - doi: 10.1117/12.2061211 
interaction. The first ETOP was held in conjunction with SPIE's annual meeting in San Diego. It brought together scientists, technicians and educators to discuss educational programs and the opportunities and challenges for graduates.

The second conference was held in 1991 in St Petersburg, Russia, for which the ICO joined the founding organizations as a co-sponsor. From there, ETOP became a biennial meeting that has been held in Pecs, Hungary (1993); San Diego, California, USA (1995); Delft, the Netherlands (1997); Cancun, Mexico (1999); Singapore (2001); Tucson, Arizona, USA (2003); Marseille, France (2005); Ottawa, Ontario, Canada (2007); and St Asaph, Wales (2009). In 2011 the conference was planned to take place in Tunis, Tunisia but was last minute cancelled.

Nowadays ETOP conferences have as permanent sponsors ICO, IEEE, OSA, and SPIE. A Long-Range Advisory Committee plans and advises on upcoming ETOP conferences.

\section{The $12^{\text {th }}$ ETOP conference}

Upon the success of the International Conference on Applications of Optics and Photonics, AOP2011, conference ${ }^{3}$ held in Braga, Portugal, May 3 to 7, 2011, the first main international event organized by the recently (mid November 2009) establish Portuguese Society for Optics and Photonics, SPOF (Figure 1.) the first author and president of SPOF was approached about the possibility of organizing in Portugal the $12^{\text {th }}$ edition of the ETOP conferences.

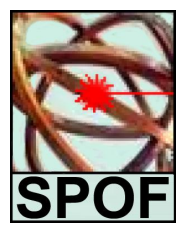

Figure 1: The logo of the Portuguese Society for Optics and Photonics, SPOF, consists of an astrolabe traversed by a shining light beam, representing the crucial contribution of optical sciences to the development of sailing that permitted the development of the

Portuguese Discoveries. The discovery of new worlds and new ways to connect different continents in an unprecedented way decisively contributed to the development and shaping of today' World.

This edition was scheduled for 2011 to be held in Tunisia but was cancelled by the ETOP Long Range Advisory Committee because of the civil unrest in the region. This possibility of organizing an ETOP conference was an honor to SPOF and the challenge was gladly accepted. ETOP'2013 was set to be held 23-26 July, 2013, in the city of Porto, Portugal, and to run in parallel and in articulated way with the "VIII Iberoamerican Optics Meeting and XI Latinamerican Meeting on Optics, Lasers and Applications, RIAO/OPTILAS2013.
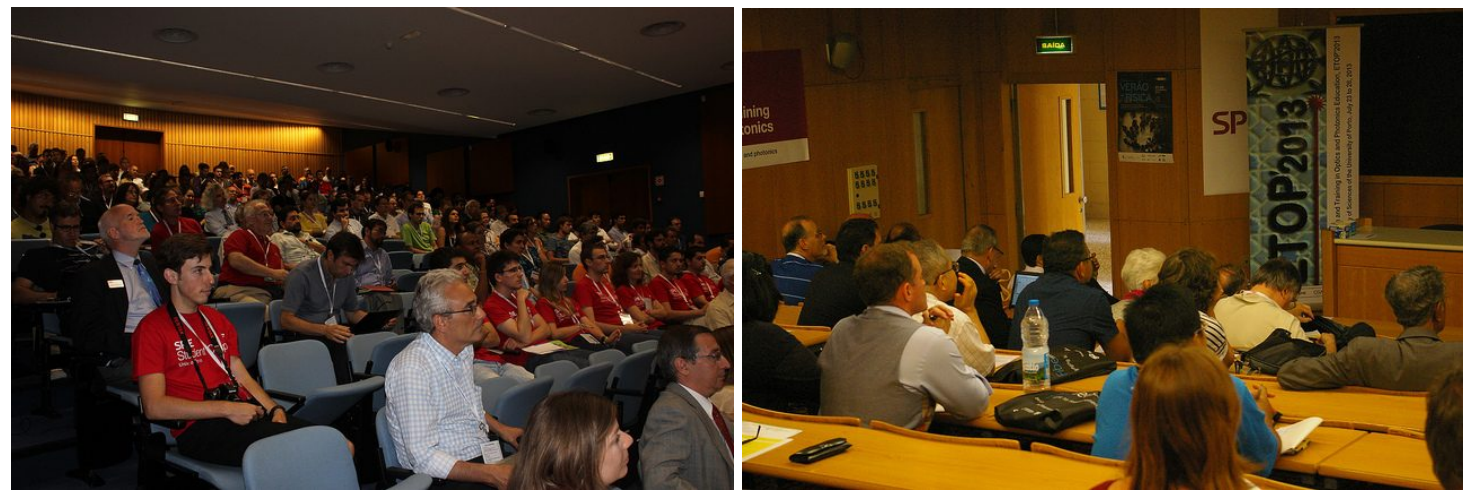

Figure 2. ETOP2013' work sessions at the Faculty of Science of the University of Porto, Portugal.

The RIAO/OPTILAS meetings take place every three years and have steadily grown establishing itself as the major scientific meeting in optics and photonics in Iberoamerica. It has been a privileged forum for friendly intense committed 
discussions and sharing of ideas and experiences in the field of optics and photonics and the establishment of cooperation among Iberoamerican institutions and optics researchers and colleagues all over the world. It long became the reference meeting in Optics in Iberoamerica and its main "window" to the world that widely recognizes the decisive importance of Iberoamerica' contribution to the development of Optics and Photonics.

It was also decided to invite the organizers of cancelled Tunis' ETOP conference to be involved in the organization of the conference. The Tunisian Optics Society (STO) embraced the project and Mourad Zghal, President of STO became co-chairperson of the conference and Prof. Zohra Ben Lakhdar of University El Manaur in Tunis, Tunisia and Prof. Vasudevan Lakshminarayanan of the University of Waterloo in Canada accepted to be Honorary Chairs of ETOP2013. ETOP2013 was therefore jointly organized by the Portuguese and Tunisian Territorial Committees of the ICO.

The event (Figure 2.) attracted over 210 participants, including 68 students, with 140 submitted works including 31 invited presentations, 5 workshops, 3 hands-on activities, 1 short course, a poster session and two special sessions run jointly with RIAO/OPTILAS2013 conference (Entrepreneurship in Optics \& Photonics session and Women \& Optics session).

It was the first ever ETOP event of this scale at which we were able to actively engage with and reach out to a wider range of delegates from 38 countries Additionally, the conference served as a forum for representatives from academia and industry as well as students and school teachers to interact and build bridges. The different sessions provided the framework of wider discussions on how to improve education, training and teaching in the field of optics and photonics. Lively discussions and debate not only during the interactive sessions but also around the coffee tables and during the social program in informal ways complemented the success of the conference open the way to the editions to follow. A strong participation of students and school teachers was sought by providing special participation conditions. This was highly appreciated and a very positive characteristics of ETOP2013 as well as the informal contacts that a nice and varied social program further promoted (Figure 3.).
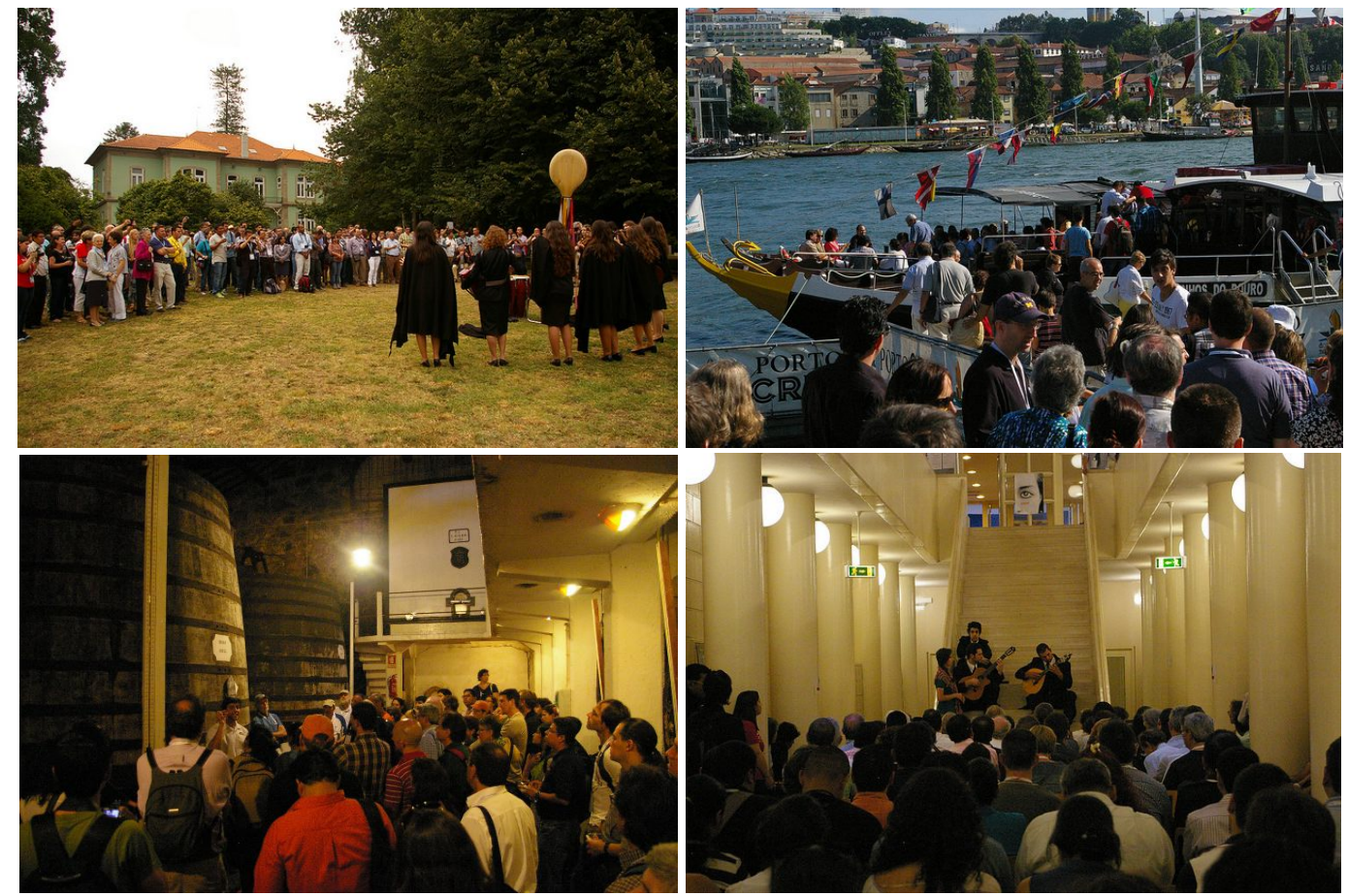

Figure 3: The lively friendly atmosphere of ETOP2013 was further potentiated by a varied social program. 
Two very interesting special sessions and round tables on "Entrepreneurship in Optics \& Photonics" and "Women \& Optics" were organized with strong active participation of the audience. These sessions were jointly organized in the frames of RIAO/OPTILAS2013 and of ETOP2013.

The joint RIAO/OPTILAS2013 - ETOP2013 special session on "Women \& Optics" (Figure 3.) transcurred in a very interesting way on Friday, July 26 under the presidency of Prof. María Josefa Yzuel Giménez (Universitat Autònoma de Barcelona, Spain) and with presentations from: Prof. Maria L. Calvo, Prof. Maria J. Yzuel, Prof Donna Strickland, Prof. Cristina Solano, the students Susana Silva and Raquel Queirós of Univ. of Porto SPIE Student Chapter, and Prof. Anna Consortini. The round table discussion counted also with the participation of Prof. Angela Guzman, Prof. Maria S. Millan, Prof. Souad Lahmar and Prof. Patricia Forbes.

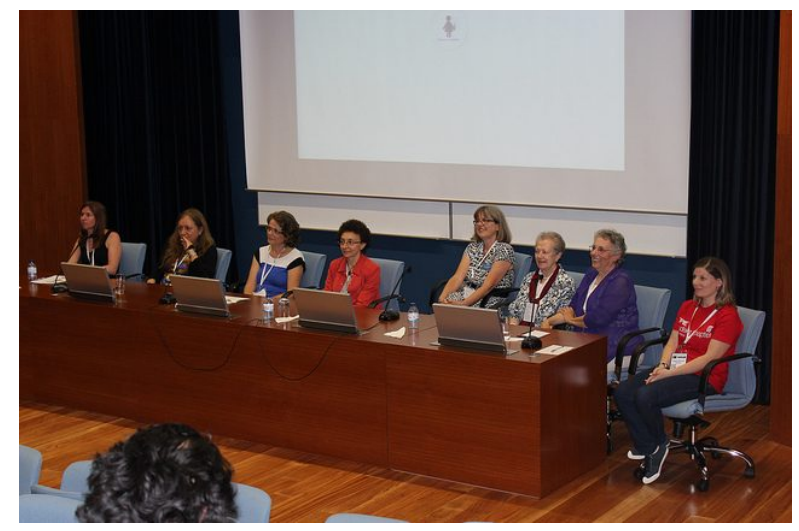

Figure 4: Joint Special Session RIAO/OPTILAS2013 - ETOP2013 "Women \& Optics".

The joint RIAO/OPTILAS2013 - ETOP2013 special session on "Entrepreneurship in Optics \& Photonics" was chaired by Prof. Duncan Moore, President of ICO, and included three lectures: "Entrepreneurship for Scientists and Engineers", Duncan Moore, University of Rochester, USA; "Research, entrepreneurship and the virtue of limits", Gerd Haeusler, Friedrich-Alexander-University Erlangen-Nürnberg, Germany; and, "Strategies for an efficacious entrepreneurship in iberoamerican countries: a proposal" Guillermo Baldwin, Pontificia Universidad Católica de Peru, Peru. The lectures were the starting point of the round table "Entrepreneurship in Optics \& Photonics" with Eric Rosas, RIAO \& CIO, Mexico; Duncan Moore, University of Rochester, USA; Gerd Haeusler, Friedrich-Alexander-University ErlangenNürnberg, Germany; Guillermo Baldwin, Pontificia Universidad Católica de Peru, Peru; Eugene Arthurs, SPIE, USA; Barry Shoop, U.S. Military Academy West Point, New York, USA; Alexandra Xavier, INESC Porto, Portugal; and Francisco Araújo, FiberSensing, Portugal. A lively and enthusiastic discussion about the many challenges and opportunities toke place with a strong participation of a nice number of students (Figure 5.).
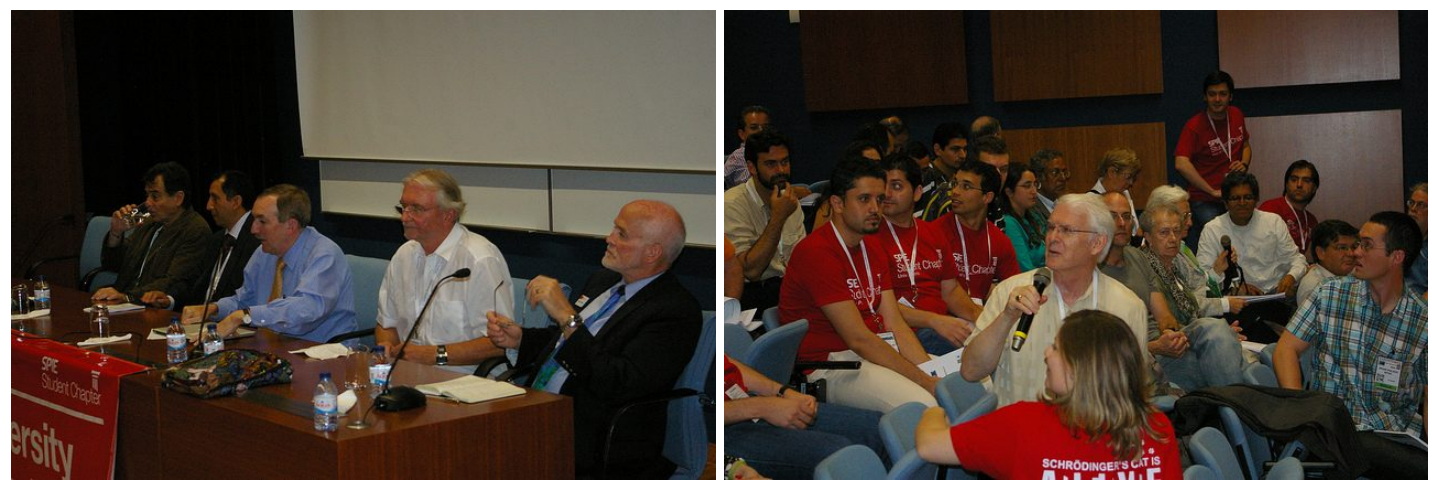

Figure 5: Very positive interaction between panelist and attendants of special session on "Entrepreneurship in Optics \& Photonics". 


\section{THE PROCEEDINGS OF ETOP}

Apart from the direct lively exchange and sharing of ideas and experiences on optics and photonics education and training, a good number of interesting papers (109) resulting from the communications to the conference were published in the proceedings of the $12^{\text {th }}$ ETOP conference.

The proceedings (Table 1) of all editions of ETOP (except the $3^{\text {rd }}$ edition in 1993) are freely available open access at http://www.spie.org/etop. This constitutes a remarkable repository and an invaluable working tool freely available to researchers and Optics and Photonics educators at all levels of formal and informal education.

Table 1. The 12 ETOP conferences.

1988 International Conference on Education in Optics

San Diego, California (USA); 14-15 August 1988

Chair and Editor: Brij M. Khorana, Rose-Hulman Institute of Technology

25 papers $^{5}$

1991 International Conference on Education in Optics

Leningrad (St.Petersburg), USSR; 28 September-1 October 1991

Cochairs and Editors: Gregory B. Altshuler, St. Petersburg Institute; Brian J. Thompson, Univ. of Rochester

75 papers $^{6}$

ICO Topical Meeting on Education \& Training in Optics

Organized by the Hungarian Optical Society OPAKFI and Janus Pannonius University for ICO

Pecs, Hungary; 16-19 August 1993

Chairs: J. Erostyak, A. Fuzessy, L. Kozma

No proceedings available ( 50 communications)

1995 International Conference on Education in Optics

San Diego, California (USA), 9-10 July 1995

Chair and Editor: M. J. Soileau, CREOL/Univ. of Central Florida

94 papers $^{7}$

Fifth International Topical Meeting on Education \& Training in Optics

Delft, The Netherlands; 19-22 August 1997

Chair: Christiaan Velzel, Nederlandse Philips Bedrijven B.V. (Netherlands)

56 papers $^{8}$

Sixth International Topical Meeting on Education \& Training in Optics \& Photonics

Cancun, Mexico; 27-30 July 1999

Chair: Javier Sanchez Mondragon, Inst. Nacional de Astrofisica, Optica y Electronica \& Univ. Aut. del Estado de Morelos (Mexico)

55 papers $^{9}$

Seventh International Topical Meeting on Education \& Training in Optics \& Photonics

Singapore, 26-30 November 2001

Chairs: Tuan-Kay Lim, Nanyang Tech. Univ. (Singapore); Arthur H. Guenther, Ctr. for High Tech. Materials/Univ. of New Mexico 78 papers $^{10}$

Eighth International Topical Meeting on Education \& Training in Optics \& Photonics

Tucson, Arizona (USA), 6-9 October 2003

Chairs: Barry Shoop, US Military Academy; Grover Swartzlander, Worcester Polytechnic Institute

111 papers $^{11}$

Ninth International Topical Meeting on Education \& Training in Optics and Photonics

Marseille, France, 24-27 October 2005

Chair: Francois Flory, Institut Fresnel, France

102 papers $^{12}$

Tenth International Topical Meeting on Education \& Training in Optics \& Photonics

Ottawa, Ontario (Canada), 3-5 June 2007

Chair: Marc Nantel, Ontario Centres of Excellence

111 papers $^{13}$

Eleventh International Topical Meeting on Education \& Training in Optics and Photonics

St. Asaph, North Wales, United Kingdom, 5-7 June 2009

Chair: Alan Shore, Photonics Academy for Wales and Bangor University, United Kingdom

Vice Chair: Deb Kane, Macquarie University, Australia

102 papers $^{14}$

Twelfth International Topical Meeting on Education \& Training in Optics and Photonics

Porto, Portugal, 23 - 26 July, 2013

Chairs: Manuel Filipe P. C. Martins Costa, Universidade do Minho, Portugal and Mourad Zghal, Université de Carthage, Tunisia 109 papers $^{15}$ 
In this $12^{\text {th }}$ edition of ETOP the distribution of the number of papers by main subject (Table 2.) reflects a focus among both researchers and educators on hands-on activities lab work and outreach as well as on computer assisted learning. Curriculum and program development are other topics of great concern. Non formal and informal education was also addressed for instance on the Hands-on Optics ${ }^{16}$ and the Hands-on Science ${ }^{17}$ projects. Young children are always eager to learn to see new things but also to know and to understand the world that surround them ${ }^{1}$. Following a trend initiated at the $11^{\text {th }}$ ETOP several papers addressed this issue of early ages education. An interesting work by Yzuel and Peinado addresses the issue of Women in Optics ${ }^{18}$ upon ETOP2013 special session on Women \& Optics ${ }^{19}$ organized together with RIAO/OPTILAS'2013 conference.

Table 2. Main topics and number of papers published at the proceedings of the $12^{\text {th }}$ ETOP conference ${ }^{15}$.

\begin{tabular}{|l|}
\hline Hands-on and Outreach (24 papers) \\
\hline Computer Assisted Learning (18 papers) \\
\hline General Concepts (18 papers) \\
\hline Curriculum Development (9 papers) \\
\hline Program Development (14 papers) \\
\hline Conceptual Understanding Assessment (5 papers) \\
\hline Training and Laboratory Demonstrations (9 papers) \\
\hline Training in Collaboration with Industry (6 papers) \\
\hline Women in Science (1 paper) \\
\hline
\end{tabular}

\section{CONCLUSIONS}

The $12^{\text {th }}$ Education and Training in Optics and Photonics, ETOP2013, was very successfully jointly organized by the Portuguese and Tunisian Territorial Committees of the ICO at the University of Porto in Portugal in July 2013. The event attracted over 210 participants from 38 countries with 140 presentations and a number of courses workshops and hands-on activities that actively involved all participants, researchers teachers and students, in a friendly lively and interactive atmosphere. The ETOP2013 conference served again as a privileged forum for representatives from academia and industry as well as students and school teachers to interact and build bridges to improve education, training and teaching in the field of optics and photonics cementing the way to successful new editions to follow. The 13th Education and Training in Optics and Photonics Conference, ETOP 2015 is being organized by PYLA - Institut Optique d'Aquitaine and Université Bordeaux and will be held at the University of Bordeaux in Bordeaux, France from 29 June to 2 July 2015.

\section{REFERENCES}

[1] Manuel F. M. Costa, Julia Campos, Madalena Lira \& Sandra Franco. Kindergarden Optics. Proc. of the Eleventh International Topical Meeting on Education \& Training in Optics and Photonics, St. Asaph, North Wales, United Kingdom, 5-7 June 2009. 3b.8.15 (2009) http://spie.org/Documents/ETOP/2009/etop2009_3b.8.15.pdf

[2] Costa MFM, The importance of experimentation on teaching the basics of optics at elementary and high schools, Proc. Soc. Photo-Opt. Instrum. Eng., 3190: 228-232 (1997). 
[3] Hands-on Physics Bibliography. Dorrío BV, Rua A, Soto R and Arias J,. Selected Papers on Hands-on Science. Costa MF, Dorrío BV, Michaelides P and Divjak S (Eds.); Associação Hands-on Science Network, Portugal. 80-88 (2008).

[4] M.F.M. Costa and B.V. Dorrío, Hands-On Optics: Training Courses For School Teachers, Proceedings of the 6th International Conference on Hands-on Science. Costa MF, Dorrío BV, Patairiya MK (Eds.); 2009, 27-31 October; Science City, Ahmedabad -India. 89-96 (2009).

[5] http://spie.org/x102146.xml

[6] http://spie.org/x102151.xml

[7] http://spie.org/x102152.xml

[8] http://spie.org/x102153.xml

[9] http://spie.org/x102154.xml

[10] http://spie.org/x102155.xml

[11] http://spie.org/x102156.xml

[12] http://spie.org/x102157.xml

[13] http://spie.org/x102158.xml

[14] http://spie.org/x102159.xml

[15] http://proceedings.spiedigitallibrary.org/volume.aspx?volumeid=16593

[16] http://spie.org/x30119.xml

[17] http://www.hsci.info

[18] M. J. Yzuel and A. Peinado, "Women in science: physics and optics", Proc. SPIE 9289, 12th Education and Training in Optics and Photonics Conference, 92892X (July 23-26, 2013); doi:10.1117/12.2070740; http://dx.doi.org/10.1117/12.2070740 (2014).

[19] http://www.optica.pt/etop2013 